\title{
"KNJIŽENSTVO": SUSRET GINOKRITIKE I DIGITALNE HUMANISTIKE'
}

U tekstu se opisuje projekat Knjiženstvo: teorija i istorija ženske književnosti na srpskom jeziku do 1915. godine, koji predstavlja napor da se obelodane i uvaže do sada najčešce nepriznavani i prećutkivani doprinosi književnica koje su pisale na srpskom jeziku. Ovaj projekat se sagledava dvojako - delom u kontekstu teorijskog nasleđa ginokritike od kojeg polazi, a u većoj meri u kontekstu trenutno vrlo aktuelne ali i kontroverzne digitalne humanistike, na koju se takođe oslanja. Tekst pokazuje da je taj oslonac svodiv na upotrebu savremenih alata pri tradicionalnim interpretativnim poduhvatima i humanističkim istraživanjima, ali i odgovara na pitanje zašto je takva upotreba u današnjem trenutku važna i dragocena.

Ključne reči: digitalna humanistika, Knjiženstvo, ginokritika, ženska tradicija, ženska književnost

1 Tekst je nastao u okviru projekta PATTERNS Lectures, koji realizuju WUS iz Austrije i Fondacija ERSTE, i projekta Uloga srpske periodike u formiranju književnih, kulturnih i nacionalnih obrazaca (178024) koji finansira Ministarstvo prosvete, nauke i tehnološkog razvoja Republike Srbije. 
Pripadnicama i pripadnicima generacija koje su odrastale, i danas odrastaju, u doba globalizacije i uz stalnu upotrebu raznih aspekata i proizvoda digitalne tehnologije, problematizacija ovih pojmova - globalizacija i digitalna tehnologija - često se čini izlišnom i banalnom. Internet velikom brzinom ispunjava sve pore našeg svakodnevnog života pa korišćenje ovog medija postaje gotovo jednako razumljivo kao i upotreba reči u neposrednoj usmenoj komunikaciji. Teško je iz takve perspektive zamisliti i rekonstruisati načine na koji su ljudi živeli, stupali u kontakt sa drugima ili pronalazili željene informacije pre samo nekoliko decenija. Još je teže poverovati da je internet nastao kao rezultat revolucionarnih društveno-političkih težnji i zamisli. U trenutku u kom je "internet odavno prestao da bude stvar izbora"” i postao široko rasprostranjen i dostupan, njegovu upotrebu više ne vidimo kao posledicu revolucionarnog čina. ${ }^{3}$ Takav doživljaj donekle je karakterističan za svaku generaciju koja je svedočila ubrzanom tehnološkom razvoju i stasavala u vreme kada se određeni medij već afirmisao i omasovio. Pa ipak, kada je reč o internetu, koji se uspostavlja kao "kulminacija razvoja elektronskih komunikacija dugih gotovo dva veka", situacija je posebno zanimljiva jer "internet ne dopušta da bude zatvoren u tradicionalno shvatanje o masovnim medijima". ${ }^{4}$ I opseg njegove upotrebe i opseg njegovog uticaja neuporedivo su širi od onih svojstvenih masovnim medijima XX veka -"čini se da je internet kolonizovao i transformisao sve što mu se našlo na putu. Još više iznenađuje činjenica da je to izgleda samo početak". 5

2 Robert V. Mekčejsni, Digitalna isključenost. Kako kapitalizam okreće internet protiv demokratije (Beograd, FMK, 2015), str. 2. Mekčejsni ukazuje na revolucionarni potencijal koji je upisan u samu ideju interneta i njegove dostupnosti, ali i na činjenicu da ta dostupnost nije sasvim ravnopravno omogućena, kao i na potencijalne opasnosti koje mogu proizići iz susreta kapitalizma, globalizacije i digitalne tehnologije (u tom pogledu, na stranama 5-15 on nudi odličan pregled dosadašnjih rasprava o ovom pitanju, deleći njihove aktere na "pobornike" i "skeptike"; za samog autora, istina se ne nalazi ni na jednom ni na drugom polu i, u krajnjem slučaju, još uvek je nemoguće otkriti je).

3 "Retko se događa da neka tehnološka zamisao uplete politiku u meri u kojoj je to učinio internet”, sažima svoje opservacije Dominik Kardon (Internet i demokratija: obećanja i granice, Beograd, Fabrika knjiga, 2013, str. 13). Budući da je internet "rođen iz susreta američke kontrakulture i meritokratskog duha istraživačkog sveta", njegovi tvorci "su materijalizovali skup vrednosti koje vrše trajan uticaj na oblik mreže, na njenu (anarhoidnu) organizaciju i na njene običaje (solidarnost)" (str. 14). Ekspanziju Mreže i njen sve presudniji uticaj na promene (odnosa između) javne i privatne sfere problematizuje i Mekčejsni.

4 Dominik Kardon, nav. delo, str. 9.

5 Robert V. Mekčejsni, nav. delo, str. 2-3. 
Jedna od oblasti koja nije bila imuna na uticaj digitalnih medija, odnosno "kolonizaciju i transformaciju", jeste oblast humanističkih nauka. Tako je u poslednjih nekoliko godina došlo do rađanja i zatim punog zamaha "digitalne humanistike". Umesto kao jasno omeđenu disciplinu ili metodološki pristup, digitalnu humanistiku treba shvatiti kao "skup konvergentnih praksi" usmernih ka nekoliko osnovnih i neupitnih ciljeva, na prvom mestu inovativnosti u proučavanju i podučavanju humanističkih nauka, te demokratizaciji znanja u načelu. ${ }^{6}$ Čitajući različite manifeste digitalne humanistike, stičemo utisak da su na njihovo formiranje najpresudnije uticala dva činioca. Prvi od njih vezuje se za sam istorijat i omasovljavanje interneta, te za potencijale koje nudi internet: $\mathrm{s}$ jedne strane, digitalna humanistika teži da očuva "utopijsku srž" interneta, proisteklu iz njegove ukorenjenosti u kontrakulturnim pokretima 60-ih i 70-ih godina 20. veka, koja podrazumeva otpor nadirućem kapitalizmu i svakom vidu sistemske opresije (ekonomske, društvene ili kulturne); s druge strane, ovaj utopistički projekat podrazumeva imperativ apsolutne otvorenosti, dostupnosti i slobodnog protoka informacija - jednom rečju, radikalne demokratizacije. Drugi činilac, koji je bitno uticao na pobornike digitalne humanistike i njihove koncepcije, prevashodno u epistemološkom, a ne u političkom pogledu (mada je te dve sfere, usled duboke i suštinske političnosti projekta, nemoguće sasvim razdvojiti), predstavlja iskustvo postmoderniteta. Tako među osnovnim načelima koja zagovaraju pobornici digitalne humanistike nailazimo i na "vrednovanje kopije nauštrb originala" (što i ne čudi, ne samo zbog prirode interneta već i zbog činjenice da su samo postojanje "originala" i mogućnost njegove spoznaje prethodno već radikalno dovedeni u pitanje), 7 ali i na zahtev za što većim zamagljivanjima i brisanjima granica svih vrsta - "između kritičara i proizvođača, programera i mislilaca, naučnika i zabavljača”. Brisanje granica podrazumeva upornu dehijerarhizaciju i decentralizaciju znanja, slobodni-

6 J. Schnapp i P. Presner, "Digital Humanities Manifesto 2.0", 2009. U nastavku teksta, osim ukoliko nije drugačije naznačeno, navodi koji se odnose na ciljeve i teze pobornika digitalne humanistike preuzeti su iz ovog manifesta, tj. sa stranice http://www.humanitiesblast.com/manifesto/Manifesto_V2.pdf.

7 Internet figurira kao "mreža, to jest ono što Delez i Gatari nazivaju rizomom. Rizom je sazdan tako da svaka staza može povesti do neke druge. Nema središta, nema periferije, nema izlaza, pošto je potencijalno beskonačan” (Umberto Eko, Ime ruže, prevela Milana Piletić, Biblioteka Novosti, Beograd, 2004, str. 468). Postmodernisti i postmodernistkinje su često u svom pisanju primenjivali "logiku" rizoma (premda on teži opiranju logici), a poststrukturalistički teoretičari i teoretičarke su radikalno dovodili u pitanje ideje "porekla”, "autorstva”, "originalnosti”. 
je i otvorenije povezivanje akademskih institucija (kojima pobornici digitalne humanistike često zameraju "institucionalnu inertnost") sa širom zajednicom, preispitivanje kategorije "ekspert/ekspertkinja" $\mathrm{i}$ njeno preplitanje sa kategorijom "kustos/kustoskinja". Od naučnika (predavača i istraživača) očekuje se da postanu aktivni baštinici i promoteri znanja, ali ne isključivo unutar "kule od slonovače" u čijim granicama se inače kreću. Oni treba da odgovore na izazove savremenog doba i vrtoglavih promena do kojih dovodi sprega globalizacije i digitalne tehnologije; da se prilagode društveno-istorijskim okolnostima u kojima se značaj i uloga humanističkog znanja i obrazovanja dovode u pitanje; da "težeći da preoblikuju i iznova osnaže savremene umetničke i humanističke prakse, kao i da prošire njihove granice” ujedno zainteresuju širu javnost za probleme kojima se tradicionalno bavi akademska zajednica u svojim jasno omeđenim okvirima; te da tu istu širu javnost, u što većoj meri, pozovu na i uključe u razmatranje tih problema. Shodno tome, još jedna od važnih karakteristika digitalne humanistike jeste insistiranje na kooperativnosti, na kontinuiranoj interdisciplinarnoj/multidisciplinarnoj/transdisciplinarnoj saradnji između stručnjaka različitih profesija, nivoa obrazovanja i interesovanja. Da ovi epiteti ne bi ostali samo "prazne reči", o njima ne treba samo govoriti, već je neophodno "izgraditi budućnost kroz projekte" u kojima bi se sva načela pobornika digitalne humanistike sprovela u praksi.

Jedan od retkih projekata u Srbiji koji to čini jeste Knjiženstvo: teorija i istorija ženske književnosti na srpskom jeziku do 1915. godine. Pokrenut je 2011. godine, uz podršku Ministarstva prosvete, nauke i tehnološkog razvoja Republike Srbije. ${ }^{8}$ Rukovoditeljka projekta je Biljana Dojčinović, redovna profesorka na Katedri za opštu književnost i teoriju književnosti Filološkog fakulteta Univerziteta u Beogradu. U projektu učestvuje dvadesetak naučnica i naučnika (njihovo matično

8 Magdalena Koh, na primer, ističe značaj ove činjenice: "važna kvalitativna promena je i u tome što projekat Knjiženstvo finansira Ministarstvo prosvete i nauke Srbije, što dokazuje da je potreba da se sakupe i učine dostupnim i vidljivim informacije o nasledstvu srpskih žena sada i zvanično priznata kao prioritetna. I tome se radujem, jer vidim da se reči Isidore Sekulić da će srpske spisateljice u periodu kada se smirimo, kada sazremo kao kultura dobiti svoje mesto polako ostvaruje" (http:// libartes.com/2013/mart/intervju/magdalena_koh.php). Entuzijazam Magdalene Koh ipak treba prihvatiti sa rezervom, naročito imajući u vidu česte promene vlasti, pa tako i kulturnih i obrazovnih politika, do kojih je dolazilo i pre i neposredno nakon što je ovaj projekat zaživeo. Pored toga, ostvarenje zamisli Isidore Sekulić još uvek se čini daleko, iako je projekat Knjiženstvo jedan od važnih koraka koji mogu voditi ka njemu. U današnjem društveno-političkom kontekstu, ti koraci su najčešće ipak vrlo spori. 
polje istraživanja uglavnom je komparativna književnost, ali i bibliotekarstvo i informatika, istorija i srodne humanističke discipline), kao i nekoliko studentkinja i studenata doktorskih studija. Kako sama rukovoditeljka u više navrata ističe, "projekat ima za cilj da osvetli istoriju ženske književnosti na srpskom jeziku, kao i da teoretizuje njene specifičnosti, preoblikujući postojeće, uglavnom zapadne, pojmove i modele". ${ }^{9}$ Shodno težnji da doprinese rekonstrukciji i razumevanju ženske književne tradicije u određenim vremensko-prostornim okvirima, ovaj projekat se u velikoj meri oslanja na teorijsko nasleđe američke ginokritike. ${ }^{10}$

Projekat Knjiženstvo: teorïa i istorija književnosti na srpskom jeziku do 1915. godine sastoji se iz dva osnovna elementa: digitalne baze podataka i elektronskog časopisa. Digitalna baza dostupna je na sajtu http://knjizenstvo.etf.bg.ac.rs i sačinjena je od osnovnih podataka o sto sedamdeset tri autorke koje su pisale na srpskom jeziku počev od srednjeg veka do 1915. godine, bez obzira na obim ili recepciju njihovih dela. U strukturu baze, dakle, nisu upisani nikakvi aksiološki kriterijumi - baza je neutralna i dehijerarhizovana platforma koja svim posetiocima sajta omogućava uvid u osnovne biografske i bibliografske podatke o popisanim autorkama, ali i ukazuje na njihove me-

9 Svi navodi u nastavku teksta koji se odnose na uredničku politiku tima koji stoji iza Knjiženstva, osim ukoliko nije drugačije naznačeno, preuzeti su, kao i u ovom slučaju, sa portala http://www.knjizenstvo.rs/.

10 Ginokritika je i inače jedno od primarnih polja interesovanja i istraživanja rukovoditeljke ovog projekta, te je njen uticaj razumljiv. Jednu od najčuvenijih i najuticijanijih podela feminističke kritike u širem smislu čini Ilejn Šouvolter, razlikujući feminističku kritiku u užem smislu i ginokritiku. Sličnu podelu iznosi i Toril Moi govoreći o dve faze feminističke kritike u Americi. Dok prvu karakteriše iščitavanje dela (često kanonskih) muških i ženskih autora u kojima se prepoznaju postupci stereotipizacije ženskih likova i različiti vidovi njihove diskriminacije koji se očituju u književnosti, druga je usmerena na žene-autorke i na rekonstruisanje i priznavanje tradicije književnosti pisane ženskom rukom. U fokusu prvog pristupa je “žena kao ona koja čita”, a u fokusu drugog “žena kao ona koja piše”. Važno je naglasiti da ginokritika ne polazi od esencijalističkih i apstraktnih pojmova poput specifičnog “ženskog senzibiliteta”, "prirode", "suštine”. Njene pobornice smatraju da tradicija i priroda ženskog pisanja jesu specifične, ali da razlog za to nije ujedinjujući skup osobina koje su inherentne ženskom polu, već društvenih i kulturnih uslova koji utiču na živote žena, čineći ih različitim od života muškaraca, što se nužno odražava i na samu književnost. Tako bi, prema Ilejn Šouvolter, ginokritika bila pristup koji se usredsređuje na ženu kao proizvođača smisla teksta, istoriju, teme, žanrove i strukture književnosti koju su pisale žene, sa ciljem da se utvrde zajedničke odlike te literature i rekonstruiše ženska tradicija. Videti: Elaine Showalter, "Towards a Feminist Poetics", u: M. Jacobus, ed. Women Writing about Women (1979) i Toril Moi, Seksualna/tekstualna politika. Feministička književna teorija, prevela s engleskog Maša Grdešić, AGM, Zagreb, 2007. 
đusobne literarne veze i osobenosti recepcije njihovih dela. U nekim, za sada retkim slučajevima, u bazi podataka nalaze se i digitalizovani tekstovi. Imajući u vidu da tim koji stoji iza projekta Knjiženstvo naglašava "nužnost stalne dopune i nadgradnje" postojeće baze, jasno je da i njima i budućim generacijama istraživačica i istraživača predstoji iscrpan i temeljan posao prikupljanja (često teško dostupne) građe i njenog digitalizovanja.

Za razliku od baze podataka, koja predstavlja rezultat kvantitativnog istraživanja (svaka praksa koja se može obuhvatiti pojmom "digitalna humanistika" u suštini započinje takvim istraživanjem; i sama digitalna humanistika je u svojoj prvoj fazi razvoja načelno bila kvantitativna), Knjiženstvo, časopis za studije književnosti, roda $i$ kulture, polazeći od baze i koristeći podatke iz baze, zapravo postaje prostor "kvalitativnih" istraživanja (isto se, ponovo, može reći i za razvoj digitalne humanistike u celini, koja je u drugom koraku "po svom karakteru kvalitativna, interpretativna, empirijska, emocionalna i stvaralačka"). ${ }^{11}$ Časopis je "zamišljen kao prostor u kome mapa ženske književnosti u nastajanju biva uobličena u narativ, oživljena kao niz dijaloga, obrazlagana, preispitivana, teoretizovana i povezana sa različitim pristupima i disciplinama". Tekstovi koji se u njemu objavljuju, svrstani u rubrike "Uvodna reč", "Ženska književnost i kultura", "Bibliografije”, "Intervju”, "Prikazi” i "Događaji”, mahom se tiču ženske književnosti (uglavnom, mada ne i isključivo, napisane na srpskom jeziku, ali u periodu širem od onog koji je omeđen bazom podataka), ali i tematizuju položaj žene kao Drugog iz perspektive različitih humanističkih disciplina, prvenstveno istorije, sociologije, studija periodike i drugih. Analizama i tumačenjima "ženske književnosti i kulture" pristupa se iz različitih uglova i uz upotrebu različitih adekvatnih interpretativnih metoda "da bi ona značenja koja su u drugim pristupima odbačena kao trivijalna ili nejasna zbog svoje obojenosti rodom ponovo oživela". ${ }^{12}$

Kao što su za formu i sadržaj projekta Knjiženstvo od presudnog značaja uticaj ginokritičkog teorijskog nasleđa i mogućnosti koje nude digitalne tehnologije, tako ovaj projekat mnogo duguje i prethodnim, znatno ranijim, pokušajima i naporima da se žensko književno stvaralaštvo na srpskom jeziku istraži i katalogizuje. Biljana Dojčinović ističe ulogu i uticaj koji su, u tom pogledu, imali almanah

11 "Digital Humanities Manifesto 2.0". http://www.humanitiesblast.com/manifesto/ Manifesto_V2.pdf.

12 Biljana Dojčinović-Nešić, "Ginokritika: istraživanja ženske književne tradicije”, Ženske studije, br. 5-6, Beograd, 1996, str. 67. 
Srpkinja iz 1913. godine koji je uredila Jelica Belović Bernadžikovska (a koji se, sa svoje strane, oslanja na spisak iz almanaha Srpkinja za 1897. godinu), kao i Bibliografija knjiga ženskih pisaca štampanih u Vojvodini, Srbiji, Južnoj Srbiji i Crnoj gori do svršetka godine 1935, objavljena 1936. godine, a koju je sačinila Nadežda Petrović, bibliotekarka Narodne biblioteke. ${ }^{13}$ Od velikog značaja bio je i časopis ProFemina, na prvom mestu njegove rubrike "Portret prethodnice" i "Portret savremenice". Pored toga, važno je pomenuti i projekat "Women Writers in History - Toward a New Understanding of European Literary Culture" koji je sprovoden u okviru COST-a, ${ }^{14}$ sa kojim je projekat Knjiženstvo povezan. Po rečima Biljane Dojčinović, "[b]aza podataka Knjiženstvo jeste nastala po uzoru na pomenutu evropsku bazu podataka, ali se od nje razlikuje po tome što se bavi prvenstveno produkcijom, a ne recepcijom, iako i nju uključuje". Počev od 2013. godine, Knjiženstuo se povezuje sa još jednim projektom - COBWWWEB (Cooperation Between Women Writers Within European Borders). ${ }^{15}$

Šta Knjiženstvo čini za (digitalnu) humanistiku, a šta digitalna humanistika za Knjiženstvo? Kako je već rečeno, osnovni cilj tima koji stoji iza ovog projekta nije sasvim nov i revolucionaran: "ginokritički" napori rekonstruisanja i uvažavanja nepravedno zapostavljane ženske književne tradicije postojali su u Srbiji znatno pre formulisanja ginokritičke teorije na Zapadu. Međutim, ti pokušaji su potom nepravedno zapostavljeni u istorijama srpske književnosti i kulture, kao i u obrazovnom sistemu u načelu. Na izvestan način, projekat Knjiženstvo revitalizuje takve napore, dopunjava ih i preodeva u moderno ruho. Deo tog preodevanja jeste i digitalizacija, koja omogućava daleko dostupniji, sistematičniji i vidljiviji pregled ženskog stvaralaštva u određenom kontekstu. Polazeći od nekih načela digitalne humanistike, učesnice i učesnici u projektu Knjiženstvo, udruženi interdisciplinarnom saradnjom, insistiraju na slobodnom protoku informacija i demokratizaciji znanja, pa tako i bazi podataka i časopisu svako može pristupiti besplatno i na vrlo jednostavan način.

Primećeno je da sa "usponom Mreže i nestajanjem tradicionalnog čitanja ljudi gube linearni način mišljenja” ${ }^{16}$ Internet, dakle, utiče

13 Biljana Dojčinović, "Inovacija je uvek presedan: Knjiženstvo - digitalna humanistika i ženska književnost na srpskom jeziku”, u Kultura, u potrazi za novom paradigmom, knj. 2, Filološki fakultet, Univerzitet u Beogradu, Beograd, str. 106-107.

14 http://www.cost.eu/COST_Actions/isch/ISo9o.

15 Biljana Dojčinović, “Inovacija je uvek presedan...”, str. 114-116.

16 Robert V. Mekčejsni, nav. delo, str. 14. 
na naše poimanje stvarnosti i način na koji mislimo. Nema razloga da taj uvid ne važi i za razmišljanje o književnosti. Poslednjih godina vode se brojne debate o tom pitanju. Teoretičar Franko Moreti, tvorac više nego kontroverznog pojma "čitanje na daljinu" (distant reading), suprotstavljenog verovatno najčuvenijem konceptu američke nove kritike - "pomnom čitanju" (close reading), jedna je od najuticajnijih i najistaknutijih figura u tim debatama. Moreti zastupa tezu da je moguće uočiti i objasniti trajne i stabilne odlike književnosti, kao i dinamiku njenog razvoja, uz pomoć kvantitativne analize svih dostupnih književnih tekstova. Njegovi stavovi naišli su na brojne zamerke, pa su tako mnogi ukazivali na aporije u Moretijevom mišljenju. Neke od najvažnijih zamerki odnose se na poistovećivanje statističkog i suštinskog značaja, na nedostatak konceptualnih potkrepljenja deskriptivnih i statističkih analiza, na izostavljanje ili zanemarivanje uloge čitaoca i afektivne komponentne književnosti. ${ }^{17}$ Pored toga, Moreti se optužuje za radikalni scijentizam: "Moretijev projekat počinje da podseća na dva već poznata projekta u istoriji književnosti, koji su takođe odbacivali arbitrarnost naučnih hipoteza i samo parcijalne rezultate, a hteli naučnu egzaktnost i viziju celine: na pozitivističku istoriografiju i strukturalizam." ${ }^{18}$ Ova zamerka je na mestu, naročito ako imamo u vidu najradikalnije pripadnike pozitivističke škole, poput Ferdinanda Brinetjera, poznatog po darvinistički intoniranoj evoluciji rodova, ili pozne strukturaliste u Francuskoj. Opravdana je i pretpostavka da takvi projekti neće preživeti i ostvariti svoje dugoročne ciljeve, jer im se književnost po svojoj prirodi opire.

Upravo u želji da se ogradi od "distanciranog čitanja” koje zastupa Moreti, a koje se nekada proizvoljno i automatski poistovećuje sa metodoma pobornika digitalne humanistike u celini, Biljana Dojčinović, u tekstu "Inovacija je vuek presedan...", tvrdi da "Moretijeve ideje o proučavanju književnosti zarad iscrtavanja grafikona, mapa i stabala, koja treba da nam pruže različite preglede razvoja ideja, žanrova, motiva, međuodnosa, ne mogu biti zamena za čitanje radi razumevanja i doživljavanja, već samo pomoćno sredstvo”. Iz toga je jasno da u osnovi projekta Knjiženstvo nije puki scijentistički cilj, već želja da se jedna obimna građa, koja je bila sistemski zanemarivana i

17 U tom pogledu, paradigmatičan je sledeći tekst: Ben Merriman, "A Science of Literature”, http://bostonreview.net/books-ideas/ben-merriman-moretti-jockersdigital-humanities.

18 Zoran Milutinović, "Kako napisati istoriju svetske književnosti”, Susret na trećem mestu: ogledi iz teorije i interpretacije, Geopoetika, Beograd, 2006, nav. prema: Biljana Dojčinović, "Inovacija je uvek presedan...”, str. 111. 
marginalizovana, obelodani i učini dostupnom, upravo da bi poslužila kao polazište za pomno čitanje: "Treba uzeti u obzir vidljivost koju ovakvi pregledi obezbeđuju - vidljivost onoga što je do skoro bilo zaboravljeno, nepoznato - naročito kada se takvi sistemi pojavljuju i na internetu. Drugim rečima, ovde se protiv 'zavere nečitanja' ženske književnosti mogu koristiti 'teorije nečitanja', a sve - čitanja radi”. ${ }^{19}$ Uostalom, treba istaći da je i sama ginokritika u velikoj meri bliska pozitivističkom metodu, odnosno da su ginokritičarke, polazeći od roda kao društveno i kulturno konstruisane i uslovljene kategorije, nužno razvijale sklonost ka "obilaženju oko teksta", "udaljavanju od teksta” i objašnjavanju teksta vanknjiževnim činjenicama vezanim za kontekst njegovog nastajanja i recepcije. ${ }^{20}$ Iako predstavnice ginokritike nisu nužno imale grandiozne scijentističke planove poput Moretijevog, niti težile sveobuhvatnosti, njihov pristup nije izbegao slične postupke, koji postaju opasnost tek ukoliko prete da ponište vrednost "čitanja radi razumevanja i doživljavanja".

Još jedan cilj projekta Knjiženstuo, koji se vezuje za domen ginokritičkog nasleđa, jeste kritičko preispitivanje kanona i ideoloških pretpostavki istorije književnosti. Svojim oblikom mreže bez središta i hijerarhije, te svojom permanentnom i intencionalnom nedovršenošću, digitalna baza podataka dovodi u pitanje naizgled čvrste i dovršene koncepcije istorija književnosti ili književnih kanona. Preciznije, te koncepcije teoretičari i teoretičarke dovodili su u pitanje znatno ranije, prevashodno nakon šezdesetih godina 20. veka kada su sa osećanjem nazvanim "postmoderno stanje" rasle sumnje u "velike naracije". Uporedo sa tim javili su se napori da se zapadni kanon destabilizuje, relativizuje, te da se ukaže na njegove lakune. ${ }^{21}$ Jedna takva lakuna

19 Biljana Dojčinović, “Inovacija je uvek presedan...”, str. 111-112. Spominjući “zaveru nečitanja”, Dojčinović aludira na istraživački projekat "Zavera nečitanja: mesto, sudbina i značaj ženskog književnog stvaralaštva u srpskoj kulturnoj baštini” (2001 - 2004), u kome je učestvovala zajedno sa Vladislavom Gordić Petković, Tatjanom Rosić i Dubravkom Đurić, i koji takođe predstavlja svojevsnu preteču Knjiženstva.

20 Videti: Elaine Showalter, A Literature of Their Own: British Women Novelists from Bronte to Lessing, Princeton University Press, Princeton, New Jersey, 1977. Govoreći o bilo kojoj fazi ženske tradicije, i baveći se delom bilo koje autorke, Šouvolter prvenstveno konstruiše i proučava svojevrsnu istoriju književnosti koja se pre svega zasniva na biografskim podacima, prikupljanju i razmatranju dokumentacije i svedočanstava, kako o ličnom životu tako i o opštoj istorijskoj i kulturološkoj klimi, o pravnim i sociološkim pitanjima epohe u kojoj književnica piše, dok je interpretacija samih tekstova u poslednjem planu. U tom pogledu, zanimljivo je poglavlje o Virdžiniji Vulf, koje u neku ruku predstavlja tumačenje njenog "zdravstvenog kartona", a tek u obrisima i samih tekstova.

21 Ovom problemu je, između ostalog, posvećen i prvi broj časopisa Genero, tj. temat 
bila je marginalizovana ili prećutana ženska književnost. Svesna da se situacija u Srbiji nimalo ne razlikuje u tom pogledu, Biljana Dojčinović insistira na tome da projekat Knjiženstvo, delom upravo zahvaljujući sprezi sa digitalnom humanistikom, može da ukaže na ove probleme, te da predstavlja jedno od polazišta za njihovo rešavanje. I čini se da najdragoceniji i najvažniji doprinos ovog projekta leži upravo u tome.

Čuveni američki teoretičar Stenli Fiš posvetio je dosta pažnje problemu digitalne humanistike i njene ekspanzije u svojim blogovima koje preferira da naziva kolumnama, ne samo "jer je blog ružna reč", već i ružna pojava (što je već indikativan stav). ${ }^{22}$ Fiš problemu pristupa cinično i sa neodobravanjem, ali je u isto vreme dobro informisan i vrlo pronicljiv. On smatra da futuristička vizija kojom su prožeti manifesti digitalne humanistike, kao i tekstovi njenih zagovornika u načelu, ima dve dimenzije: "teološku, što je tvrdnja kojoj bi se njene pristalice suprotstavile, i političku, što je tvrdnja sa kojom bi se najverovatnije složili." ${ }^{23}$ Ova opaska je zanimljiva jer ukazuje na ne tako retku jalovost mesijanske crte koja se zaista može prepoznati u manifestima digitalne humanistike. Ta mesijanska crta u sprezi je sa političkom i aktivističkom oštricom "skupa konvergentnih praksi" čiji je cilj da omoguće slobodnu razmenu znanja (da šire "digitalnu anarhiju”), ali i da budu spasonosno rešenje za krizu u kojoj se humanistika nalazi već neko vreme, krizu uslovljenu snažnim prodorom kapitalističke logike u obrazovni sistem. Ona je često jalova upravo zato što ne prevazilazi nivo manifesta ili se, što je još gore, u praksi pretvara u sopstvenu suprotnost.

Kada upućuje zamerke pobornicima digitalne humanistike, Fiš uglavnom ima u vidu ponekad konfuzno preplitanje dva tipa argumenata koje oni obično zastupaju: “1) Činimo ono što ste vi oduvek činili, samo što mi imamo alate uz pomoć kojih i vi to možete učiniti bolje, pustite nas unutra; i 2) Mi smo glasnici i nosioci nove istine.”24 Dejv Peri je jedan od mnogih koji primećuju da je u najvećem broju slučajeva jedino prvi među njima osnovan - "digitalna humanistika se uglavnom ili prvenstveno svodi na upotrebu digitalnih tehnologija

o "feminističkim čitanjima i preispitivanjima književnog kanona" koji je 2002. godine uredila Biljana Dojčinović.

22 Stanley Fish, "The Digital Humanities and the Transcending of Mortality", https://opinionator.blogs.nytimes.com/2012/01/o9/the-digital-humanities-andthe-transcending-of-mortality/.

23 Isto.

24 Stanley Fish, "Mind Your P's and B's: The Digital Humanities and Interpretation”, https://opinionator.blogs.nytimes.com/2012/01/23/mind-your-ps-and-bs-thedigital-humanities-and-interpretation/. 
kao alata pri obavljanju tradicionalnih humanističkih istraživanja”. ${ }^{25}$ Proklamovana revolucionarnost najčešce nije utemeljena. Pa ipak, to ne znači da doba globalizacije u kojem živimo ne utiče na promene $u$ razumevanju i tumačenju književnosti, koje je tek potrebno sagledati i teoretizovati. U nekoj meri, alarmantnost situacije zahteva radikalne odgovore i proglase: u doba sveopšte "kolonizacije i transformacije" koju nameće i realizuje internet, stare istine i stari metodi takođe iziskuju transformaciju. Da li ćemo ih nazvati novim i revolucionarnim pristupima (iz taktičkih ili nekih drugih razloga) ponekad je od sekundarnog značaja. Ono što je važno jeste pokušaj njihovog saobražavanja novim uslovima u cilju širenja prostora u kom će susret sa književnošću biti moguć. Svesne svih prednosti i ograničenja digitalne humanistike, naučnice i naučnici koji stoje iza projekta Knjiženstvo na izvestan način spajaju oba: kada je reč o metodologiji, one i oni zaista čine sve ono što se i ranije činilo, povremeno se služeći "novim alatima", u čemu im znatno pomaže digitalna tehnologija; uporedo s tim, one i oni iznose na videlo "nove istine" o ženskoj književnoj tradiciji na srpskom jeziku, i, uprkos tome što su te istine rezultat najčešće uobičajenog naučno-istraživačkog rada ili interpretativnih poduhvata, one postaju svima dostupne i bliske zahvaljujući digitalnoj tehnologiji.

25 Dave Parry, "The Digital Humanities or Digital Humanism”, u Debates in the Digital Humanities, ed. Matthew K. Gold, University of Minnesota Press, Minneapolis, London, 2012, str. 430. 


\section{LITERATURA}

Knjiženstuo: teorija i istorija ženske književnosti na srpskom jeziku do 1915. godine, www.knjizenstvo.rs i http://knjizenstvo.etf.bg.ac.rs.

Dojčinović-Nešić, Biljana. "Ginokritika: istraživanja ženske književne tradicije”. U Ženske studije, br. 5-6, Beograd, 1996, str. 65-85.

Dojčinović, Biljana. "Inovacija je uvek presedan: Knjiženstvo - digitalna humanistika i ženska književnost na srpskom jeziku”. U Kultura, u potrazi za novom paradigmom, knj. 2. Filološki fakultet, Univerzitet u Beogradu, Beograd, str. 105-120.

Eko, Umberto. Ime ruže. Prevela Milana Piletić. Biblioteka Novosti, Beograd, 2004.

Fish, Stanley. "Mind Your P's and B's: The Digital Humanities and Interpretation". https://opinionator.blogs.nytimes.com/2012/01/23/ mind-your-ps-and-bs-the-digital-humanities-and-interpretation/ (27. 9. 2017).

Fish, Stanley. "The Digital Humanities and the Transcending of Mortality". https://opinionator.blogs.nytimes.com/2012/01/o9/the-digital-humanities-and-the-transcending-of-mortality/ (27. 9. 2017).

Koh, Magdalena, "Neodređenost termina žensko pismo je štetna za recepciju tradicije". Intervju vodila Milena Ilić. Libartes, broj IX, mart 2013, http://libartes.com/2013/mart/intervju/magdalena_koh. php (27. 9. 2017).

Mekčejsni, Robert. Digitalna isključenost. Kako kapitalizam okreće internet protiv demokratije. FMK, Beograd, 2015.

Merriman, Ben. "A Science of Literature”. http://bostonreview.net/ books-ideas/ben-merriman-moretti-jockers-digital-humanities (27. 9. 2017).

Parry, Dave, "The Digital Humanities or Digital Humanism”. U Debates in the Digital Humanities, ed. Matthew K. Gold. University of Minnesota Press, Minneapolis, London, 2012, 429-437.

Schnapp, J. and P. Presner. "Digital Humanities Manifesto 2.0". http://www.humanitiesblast.com/manifesto/Manifesto_V2.pdf

Showalter, Elaine. A Literature of Their Own: British Women Novelists from Bronte to Lessing. Princeton University Press, Princeton, New Jersey, 1977. 
"KNJIŽENSTVO": THE MEETING PLACE OF GYNOCRITICISM AND DIGITAL HUMANITIES

This essay is a brief presentation of the scientific project Knjiženstvo: Theory and History of Women's Writing in Serbian until 1915. This project is an effort to disclose and acknowledge literary contributions of women writers in Serbian language, which have mostly been neglected and elided so far. It is examined in a twofold manner - partly in the context of the theoretical heritage of gynocriticism on which it is based, and to a larger extension in the context of (at this moment very popular but also very controversial) digital humanites, to which it also relates. The essay shows that we can reduce this relation to application of the modern tools in the traditional interpretation of literature and humanistic research, but it also explains why that kind of application is important at the moment.

Keywords: digital humanities, Knjiženstvo, gynocriticism, women's tradition, women's literature 